\title{
PERANAN TEKNOLOGI INFORMASI DALAM MENDUKUNG BISNIS UMKM IBU RUMAH TANGGA DI KELURAHAN BANJAR SUGIHAN RW 01, KECAMATAN TANDES SURABAYA
}

\author{
Suzana Dewi ${ }^{1}$ \\ ${ }^{1}$ Universitas Wijaya Putra Surabaya \\ Isnaini Muhandhis ${ }^{2}$ \\ ${ }^{1}$ Universitas Wijaya Putra Surabaya
}

emails suzanadewi@uwp.ac.id, imuhandhis@gmail.com

\begin{abstract}
Abstrak
Kelurahan Banjar Sugihan RW 01 terdiri dari 6 Rukun Tetangga. Warga RW 01 adalah warga yang sibuk, para ibu-ibu RW 01, kebanyakan hanya menggunakan gadget sebagai sarana media sosial saja. Tentu saja hal ini sangat disayangkan, mengingat penggunaan gadget yang terhubung dengan internet sebenarnya dapat digunakan untuk kegiatan lain yang menghasilkan manfaat. Warga RW 01 memiliki kegiatan UMKM (Usaha Mikro Kecil dan Menengah) yang memiliki potensi sangat bagus. Misalnya, ada UMKM Jamu dan UMKM Jajan Pasar. Usaha ini sudah berlangsung bertahun-tahun lamanya dengan kemasan tanpa merek dan label. Pemasaran produk juga dilakukan secara konvensional tanpa memanfaatkan teknologi yang telah ada.

Oleh karena itu, kegiatan PKM ini bertujuan untuk memberikan pelatihan dan penyuluhan kepada ibu-ibu rumah tangga RW 01 Banjar Sugihan mengenai pengelolaan UMKM dan "Internet Positf". Dengan adanya kegiatan pengabdian ini, diharapkan UMKM yang di kelola ibu-ibu ini dapat lebih berkembang lagi dengan kemasan yang lebih menarik dan dapat melakukan pemasaran online. Adapun metode pendampingan secara intelektual digunakan untuk membentuk karakter ibu-ibu RW 01. Hal ini diharapkan dapat mengubah pemahaman dan pemikiran yang lebih baik dengan penerapan internet positif berupa pemanfaatan Teknologi Informasi.
\end{abstract}

Sebagai hasilnya Warga RW 01 yang memiliki UMKM dan warga yang akan mendirikan UMKM merasa menerima manfaat dengan adanya sosialisasi yang telah dilakukan. Pendampingan ini membuat kemasan produk menjadi lebih menarik, dan produk kini memiliki merek sendiri sebagai identitas yang membedakan dengan produk sejenis lainnya jika memang ada di pasaran dan selain itu, produk dapat dipasarkan secara online.

Kata Kunci : Teknologi Informasi, pemasaran online, pembuatan label UMKM. 


\section{PENDAHULUAN}

Kelurahan Banjar Sugihan RW (Rukun Warga) 01 terdiri dari 6 RT (Rukun Tetangga). Gambaran situasi yang dihadapi warga RW 01 adalah warga yang sangat sibuk, memiliki karang taruna, namun pasif, bisa dikatakan hampir tidak ada kegiatan masyarakat yang melibatkan pemuda pemudi di warga tersebut. Disamping itu, di daerah RW 01 Kelurahan Banjar Sugihan pada jam 18.00 - 21.00 WIB, masih didapati banyak anak yang tidak melaksanakan kegiatan belajar, walaupun mereka memiliki aset yang luar biasa, yaitu sebuah taman bacaan yang tersedia di Balai RW. Namun, sangat disayangkan bahwa Taman bacaan yang ada, jarang sekali di kunjungi anak-anak, justru ibu-ibu setempat membiarkan anak-anak mereka bermain gadget yang terhubung dengan internet tanpa pengawasan.

Pemahaman para warga terhadap internet sehat sangat minim. Waktu yang digunakan anak - anak untuk bermain sambil belajar, sangat minim. Anakanak di tingkat TK sampai dengan SMP justru lebih banyak bermain game online bukan game sebagai sarana edukasi.

Begitu juga dengan ibu-ibu RW 01, kebanyakan hanya menggunakan gadget sebagai sarana media sosial saja. Tentu saja, hal ini sangat disayangkan, mengingat penggunaan gadget yang terhubung dengan internet sebenarnya dapat digunakan untuk kegiatan lain yang produktif dan dapat menghasilkan manfaat secara ekonomis dan pengetahuan.

Di lain sisi, warga RW 01 memiliki sebuah potensi yang luar biasa, yaitu memiliki UMKM (Usaha Mikro Kecil dan Menengah). Misalnya ada UMKM Jamu dan UMKM Jajan Pasar. Usaha ini sudah berlangsung bertahun-tahun meski tanpa label dan merek.

Menurut Hamzah B. Uno dan Nina Lamatenggo (Mudjiono, 1999), Teknologi Informasi adalah suatu teknologi yang digunakan untuk mengolah, memproses, mendapatkan, menyusun, menyimpan, memanipulasi data dalam berbagai cara untuk menghasilkan informasi yang berkualitas, yaitu informasi yang relevan, akurat dan tepat waktu.
Richard Weiner dalam Websters New Word Dictinonary and Communication juga menyebutkan bahwa bahwa Teknologi Informasi adalah pemprosesan, pengolahan, dan penyebaran sata oleh kombinasi komputer dan telekomunikasi. (Sa'ud, 2008)

Dari definisi diatas dapat disimpulkan bahwa peranan teknologi sangat penting dalam berbagai bidang, salah satunya bidang pendidikan dan bisnis UMKM. Salah satu bagian penting dari teknologi informasi adalah internet. Dengan internet seluruh jaringan komputer dunia akan terhubung. Internet dapat mempermudah pemasaran elektronik atau penjualan online. Dengan menggunakan perangkat seperti handphone atau gadget yang umum dimiliki ibu-ibu rumah tangga. Kita bisa terhubung dengan jutaan calon pembeli yang adalah pengguna internet. Oleh karena itu, kegiatan PKM ini bertujuan untuk memberikan pelatihan dan penyuluhan kepada ibuibu rumah tangga RW 01 Banjar Sugihan mengenai pengelolaan UMKM dan "Internet Positf". Dengan adanya kegiatan ini diharapkan dapat meningkatkan kreatifitas anak-anak dalam penggunaan internet kea rah yang positif, membantu UMKM RW 01 Banjar Sugihan yang di kelola ibu-ibu ini dapat lebih berkembang lagi dengan kemasan yang lebih menarik dan dapat melakukan pemasaran online. Adapun metode pendampingan secara intelektual digunakan untuk membentuk karakter ibu-ibu RW 01. Pentingnya mengubah pemahaman dan pemikiran yang lebih baik dengan penerapan internet sehat agar UMKM ini terus berjalan.

\section{METODE}

Untuk mencapai tujuan yang telah disebutkan di atas, maka beberapa metode yang digunakan yaitu:

a. Metode belajar dan bermain dengan anakanak agar suasana menjadi seru dan mereka menjadi antusias untuk belajar dengan target kepada bapak atau ibu-ibu untuk bisa mengetahui soal internet sehat hingga nanti ilmunya bisa diterapkan dalam berbagai aktivitas kehidupan sehari hari. 
b. Metode pendampingan secara intelektual untuk membentuk karakter ibu-ibu RW 01 untuk mengubah pemahaman dan pemikiran yang lebih baik dengan penerapan internet sehat.

c. Memberikan pelatihan kepada ibu-ibu warga RW 01 Kel. Banjar Sugihan mengenai cara mendesain kemasan jamu agar lebih menarik, desain kemasan disesuaikan dengan persyaratan Dinkes

\section{HASIL DAN PEMBAHASAN}

Kegiatan pengabdian dilakukan pada tanggal 25 Agustus 2018 di Balai RW 01 Kel. Banjar Sugihan, Kec. Tandes Surabaya. Kegiatan dimulai pukul 08.00 WIB dan diawali dengan kegiatan pendampingan kreatifitas anak. Kegiatan ini bertujuan untuk meningkatkan kreaifitas mereka dengan cara membuat layang-layang dan lain-lain untuk mengurangi ketergantungan mereka terhadap handphone.

Kegiatan dilanjutkan dengan memberi penyuluhan kepada ibu-ibu RW 01 mengenai UMKM dan potensi - potensinya, termasuk hal - hal seperti cara pemasaran produk, yang mencakup pengemasan dan pembuatan logo yang menarik. Kegiatan selanjutnya adalah penyuluhan tentang "Internet Positif" kepada warga RW 01. Penyuluhan dengan tema "Internet Positif" ini memperkenalkan sisi positif penggunaan internet untuk menambah wawasan para ibu - ibu, salah satunya pengenalan marketplace sehingga mereka bisa lebih kreatif dalam memasarkan produk. Kegiatan diakhiri dengan memberikan pelatihan dan pendampingan kepada ibu-ibu warga RW 01 untuk membuat label dan merk produk yang mereka punya menggunakan aplikasi "Photoshop" melalui laptop atau aplikasi "Logo Maker" melalui handphone. Kegiatan praktek pembuatan desain kemasan produk jamu dibantu oleh para mahasiswa.

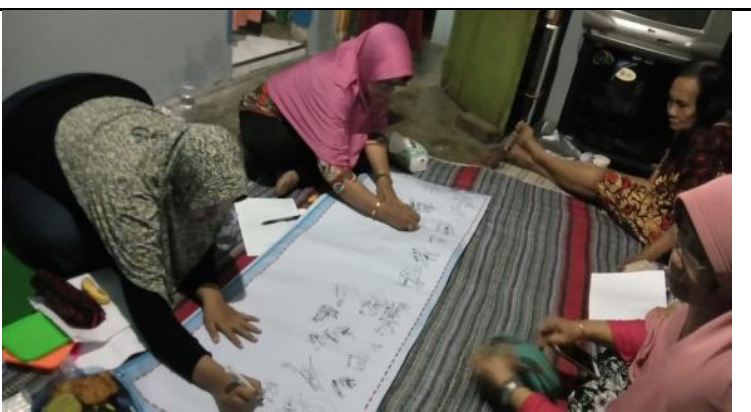

Gambar 1. Pendampingan ibu-ibu rumah tangga

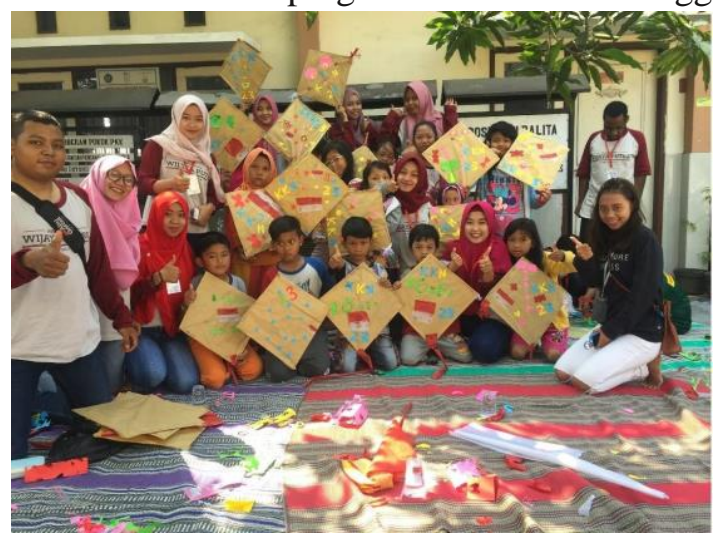

Gambar 2. Pendampingan Kreatifitas Anak

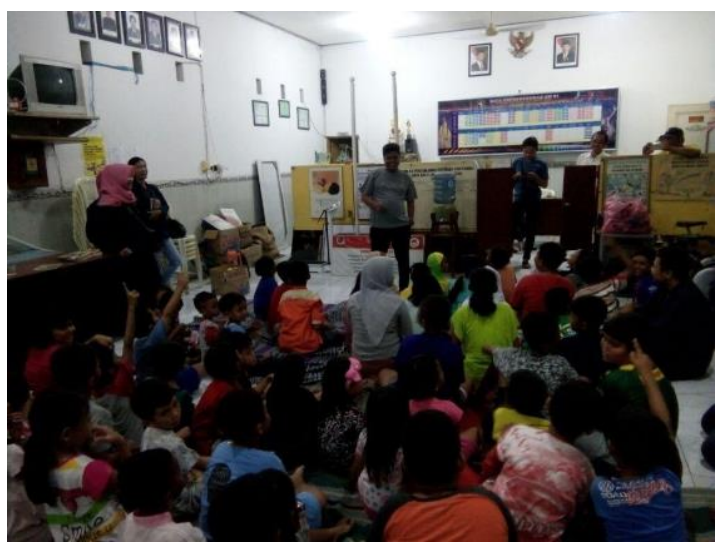

Gambar 3. Pendampingan Internet Positif 


\section{Nama Pangan Olahan UMKM}
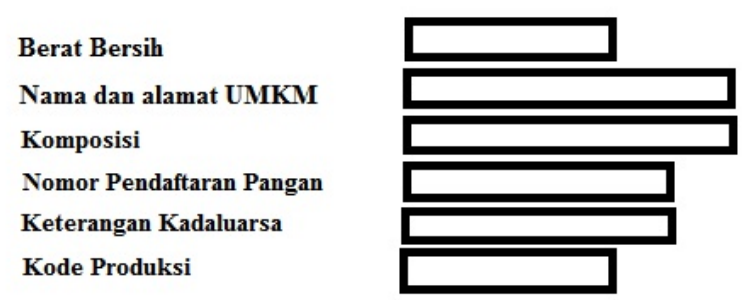

Gambar 4. Desain Label Merek UMKM

Sebagai hasil akhir dari kegiatan pengabdian ini, saat ini produksi UMKM ibu-ibu di RW $01 \mathrm{Kel}$. Banjar Sugihan telah memiliki kemasan produk yang lebih menarik dan produk kini memiliki merek sendiri sebagai identitas yang membedakan dengan produk sejenis lainnya. Selain itu, produk dapat dipasarkan secara online.

Produk UMKM yang telah memiliki label siap untuk dipasarkan secara online dengan cara membuat toko elektronik gratis menggunakan website bisnis online karya anak bangsa yang cukup banyak diminati oleh calon pembeli produk. Pendampingan berupa pembuatan akun dan tata cara berjualan online diharapkan dapat meningkatkan pemanfaatan penggunaan internet positif.

Selain itu warga RW 01 yang memiliki UMKM dan warga yang akan mendirikan UMKM merasa sangat mendapat manfaat dengan adanya sosialisasi melalui pelatihan ini, karena mendapat ilmu-ilmu baru yang dapat dikembangkan untuk usaha mereka dan desain produk mereka menjadi lebih menarik.

\section{KESIMPULAN}

Dengan adanya kegiatan pendampingan dan berbagai penyuluhan kepada ibu - ibu, potensi
UMKM mereka bisa ditingkatkan sehingga bisa memiliki daya saing yang bagus di pasaran, mereka bisa memiliki merek yang bagus sebagai identifikasi, dan mereka juga bisa memanfaatkan internet dengan maksimal, tidak menjadikan internet semata - mata sebagai media sosial saja.

\section{SARAN}

Agar bisa selalu konsisten kegiatan ini, maka ibu ibu harus senantiasa mengikuti perkembangan teknologi dan informasi, sehingga mereka bisa update dan tidak ketinggalan dalam mengembangkan produk, sehingga produk bisa senantiasa di terima oleh pasar, tidak boleh cepat puas dengan keberhasilan saat ini, harus dikembangkan terus menerus.

\section{UCAPAN TERIMAKASIH}

Ucapan terima kasih kami ucapkan kepada segenap warga di Kelurahan Banjar Sugihan RW 01, Kecamatan Tandes Surabaya beserta civitas akademika Universitas Wijaya Putra yang turut serta melaksanakan kegiatan pengabdian.

\section{REFERENSI}

Mudjiono, D. d. ( 1999). Belajar dan Pembelajaran. Jakarta: PT. Rineka Cipta.

Sa'ud, U. S. (2008). Inovasi Pendidikan. Bandung: AlfaBeta. 